\title{
The rise of technocratic cabinets What we know, and what we should like to know
}

\author{
Miloš Brunclík1,* \\ 1 Institute of Political Studies, Faculty of Social Sciences, Charles University in Prague, Czech Republic \\ * E-Mail: milos.brunclik@fsv.cuni.cz
}

\begin{abstract}
The article looks into the issue of technocratic cabinets, an increasingly common phenomenon exemplified by recent cases of technocratic governments being established in several European countries. Despite the growing prevalence of such cabinets, there is a lack of literature on the given issue. Scholars have addressed technocratic cabinets mostly through single-case studies that confined themselves to analysing technocratic cabinets in individual countries; there are almost no comparative studies. This fact leaves a number of pending questions open to further research. The article reviews major findings from studies on technocratic cabinets conducted to date, critically assesses and improves some of the concepts and presents key questions yet to be addressed in the researching of technocratic governments across Europe.
\end{abstract}

\section{Keywords:}

technocratic cabinet, non-partisans, partisans, caretaker cabinet

\section{Der Anstieg von technokratischen Regierungen Was wir wissen und was wir gerne wissen würden}

\section{Zusammenfassung}

Der Artikel beschäftigt sich mit dem Thema der so genannten technokratischen Regierungen (Beamtenregierungen), die derzeit allmählich zum Phänomen werden. Dies kann mit Fällen der neulich entstandenen technokratischen Regierungen in vielen europäischen Ländern belegt werden. Trotz häufigerer Verbreitung der Beamtenregierungen mangelt es an der Literatur zu diesem Thema. Wissenschaftler setzen sich mit den technokratischen Regierungen meistens durch die Einzelfallstudien auseinander; es fehlt jedoch an Vergleichsstudien. Diese Tatsache lässt eine Reihe von Fragen unbeantwortet. Damit öffnet sich ein breites Forschungsfeld. Dieser Artikel analysiert den aktuellen Forschungsstand zum Thema der Beamtenregierungen, verbessert einige der angewandten Konzepte und stellt Schlüsselfragen dar, die untersucht werden sollten.

\section{Schlüsselwörter:}

technokratische Regierung (Beamtenregierung), Nicht-Parteien-Regierung, Parteien-Regierung, Übergangsregierung

This article has been elaborated within the research project no. 15-01907S (title: „Does Direct Election Matter? Analyzing Effect of Direct Election of President on the Working of the Political Regime in the Czech Republic“). The project is sponsored by the Grant Agency of the Czech Republic.

The author has declared that no competing interests exist. 


\section{Introduction}

The issue of technocratic cabinets is hardly a new one in comparative politics. Such cabinets have occasionally appeared in European polities: notably in Finland (under the presidency of U. Kekkonen) and Portugal (under the presidency of A. R. Eanes) during the Cold war period. More recently (during the first decade that followed the collapse of the communist regimes) a number of technocratic cabinets were established in East-Central Europe ${ }^{\mathrm{I}}$. Finally, over the past decade or so, Europe witnessed a new wave of technocratic cabinets: Monti (20II-I3) in Italy, Raykov (2013), Oresharski (2OI3-I4) and Bliznashki (2OI4) in Bulgaria, Fischer (2009-IO) and Rusnok (2013-4) in the Czech Republic, and Papademos (2OII-2) and Pikrammenos (20I2) in Greece. Perhaps owing to this simultaneous rise of technocratic cabinets in some of these countries, it appeared as if there had been a "technocratic turn" in European politics (Pastorella 20I3, I; cf. Hopkin 20I2). But this conclusion might be something of an exaggeration. Nevertheless, the relatively significant number of empirical cases of this type of cabinet contrasts with a lack of relevant studies on the theme ${ }^{2}$. The theme has rather remained on the periphery of political science. Cabinets in democratic countries are generally perceived as partisan cabinets, i.e. cabinets composed of members of political parties which have taken seats in national parliaments ${ }^{3}$. The subject of partisan cabinets dominates most of the current comparative literature (e.g. Blondel/Müller-Rommel I988; Laver/Schofield I998; Blondel/Müller-Rommel 20oI; Laver/Budge 2002). In contrast, technocratic cabinets are often omitted from scholarly literature ${ }^{4}$, and, if indeed scholars mention the phenomenon at all, they only briefly comment on the topic (often in footnotes) and usually regard such cabinets as exceptional or deviant cases and offer no further analysis (e.g. Herman/ Pope 1973). Moreover, a number of studies dealing with government coalitions have explicitly excluded these cabinets from their scope (cf. Hloušek/Kopeček 20I4, I324). In sum, very little relevance has been attributed to the technocratic cabinets that have arisen. As Strøm, Müller and Bergman put it: "....non-partisan cabinets are exceptional with respect to incidence, duration, and relevance" (Strøm et al. 2008, 7).

I E.g. the Ahmeti (199I) and Bufi (I99I-2) cabinets in Albania, Berov (19924) and Indzhova (1994-5) in Bulgaria, Vähi (1992) in Estonia, Lubys (199I-2) and Vagnorius (1992-3) in Lithuania, Stolojan (I99I-2) and Vacaroiu (1992-6) in Romania, Tošovský (1998) in the Czech Republic, etc.

2 We put aside the literature which deals with "technocracy" as such (e.g. Meynaud I969; Putnam 1977; Bryld 2000) and technocrats in terms of civil servants, who, however, do not reach the highest political positions (e.g. Suleiman 1977).

3 In this article we take account of parliamentary (or semi-presidential) regimes in which cabinets usually arise with accountability to a parliament, and with the latter able to express no-confidence in the former.

4 In contrast, technocratic cabinets in non-democratic regimes or illiberal democracies have already attracted some scholarly attention (e.g. Milne 1982; Huskey 20IO; Schleiter 2013).
As a result, we know very little about the technocratic cabinets in question. True, there exist studies focused on technocratic cabinets but they address only particular cases. It is no coincidence that a number of publications devoted to these cabinets stem from Italy where this kind of government has already been established as a "tradition" (Grimaldi 20II; Marangoni 20I2; Pasquino/Valbruzzi 2012; Verzichelli/Cotta 2012; Zulianello 20I3; Marangoni/Verzichelli 2015). Moreover, in the Czech Republic some scholars analyse technocratic cabinets as they are far from being a mere deviation in Czech government politics (Tucker 2000; Hloušek/Kopeček 20I2; Hloušek/Kopeček 20I4). Finally, some scholars analyse technocratic cabinets in relations to accountability, legitimacy, constitutionality, political neutrality, representation (Schudson 2006; Pastorella 2015).

However, there have been no serious attempts at moving beyond country-specific studies, at analysing the technocratic cabinets in a comparative perspective or at offering a general conceptualisation of this phenomenon. To the best of our knowledge, the only exception is a study by McDonnell and Valbruzzi $(2014)^{5}$. The question of technocratic cabinets touches upon important issues in the study of politics and government in contemporary Europe ${ }^{6}$. Thus, this article reviews major findings from research conducted to date on technocratic cabinets, seeks to improve some of the concepts and presents key questions that need to be addressed in the study of technocratic governments across Europe. This article discusses the question of the conceptualisation of technocratic cabinets and several important characteristics which are commonly attributed to technocratic cabinets: their composition, remit and term of office. The article also discusses conditions under which technocratic cabinets are formed.

\section{Conceptualisation of technocratic cabinets}

Undoubtedly, most governments in European polities are partisan governments (Müller/Strøm 2000, I). The logical counterpart of this phenomenon is cabinets composed of "technocrats". Drawing a clear line between politicians and technocrats is quite difficult. Technocrats are not necessarily "neutral", but often have close ties to political parties. Conversely, some

5 There are also two conference papers by Giulia Pastorella (Pastorella 20I3; Pastorella 2014).

6 It is also complementary to numerous studies that focus on explaining the presence of non-partisans in political cabinets (Amorim Neto/Strøm 2002; Amorim Neto/Strøm 2006; Schleiter/Morgan-Jones 2009). Yet, these studies are not concerned with "technocratic cabinets" per se. 
politicians operate almost as neutral technocrats (for a discussion on technocracy see Meynaud 1968, 2I-70; Collier 1979, 403; Silva 2010, 4). Given the difficulties in distinguishing the two categories, it seems practical (notably in comparative studies with a large number of cases) to use a clear-cut and plain criterion of formal political party membership and thus define technocrats as those (prime) ministers who are not members of any political party.

As far as the concept of the technocratic cabinet is concerned, the most recent definition was suggested by McDonnell and Valbruzzi and comes from R. Katz's conditions for party government (Katz 1986; Katz 1987). McDonnell and Valbruzzi define the technocratic cabinet as a reverse mirror image of the party government and present the following ideal type of technocratic government: "(I) All major governmental decisions are not made by elected party officials. (2) Policy is not decided within parties which then act cohesively to enact it. (3) The highest officials (ministers, prime ministers) are not recruited through party" (McDonnell/Valbruzzi 20I4, 656). However, the operationalisation of this definition may not be an easy task with regard to extremely diverse political practices. For example, it may not always be easy to determine whether cabinet policies are decided within parties or not, or whether the highest officials are recruited through parties (see below). There is also the problem of how cabinets that include both partisans and technocrats (non-partisans) should be classified. Strøm, Müller and Bergman argue that in non-partisan (i.e. technocratic) cabinets "no party has any recognized representation in the cabinet (even though some of the cabinet ministers may happen to be party members)" (Strøm et al. 2008,7 , emphasis added). This finding, however, is not helpful for operationalisation. Hloušek and Kopeček suggest a new term: "semi-political" cabinets. These cabinets are located between the ideal type of political cabinet (composed exclusively of partisans) and the ideal type of technocratic cabinet (composed exclusively of technocrats) (Hloušek/Kopeček 2012, I8). Similarly, other studies (in order to distinguish between the two types of cabinets) try to discern whether a cabinet is dominated by representatives of political parties or non-partisans (technocrats) (Schleiter/Morgan-Jones 2005, 9; see also Protsyk 2003, I079). Yet this criterion does not stand the test of political practice. For example, the cabinet formed by Josef Tošovský in the Czech Republic in I998 is commonly regarded as technocratic (McDonnell/ Valbruzzi 20I4; Pastorella 2OI3; cf. Hloušek/Kopeček 2OI2, 62; Hloušek/Kopeček 20I4). However, most of the cabinet ministers were partisans (62 percent). Thus, Schleiter and Morgan-Jones (2005) or Protsyk would probably be forced to label this cabinet as a political one. McDonnell and Valbruzzi begin with a similar approach. They distinguish between: a) technocratic cabinets with a majority of partisans, and b) technocratic cabinets with a majority of technocrats. However, they add one more criterion. Even those cabinets in which political representatives outnumber technocrats are classified as technocratic, on the condition that they are led by a technocrat. McDonnell and Valbruzzi call these cabinets "technocrat-led governments." Other scholars agree that the role of prime minister is a key to understanding the technocratic cabinet. For a government to be classified as technocratic, the prime minister must be a technocrat (i.e. a non-partisan figure) (cf. Pastorella 2014, 2). This is especially important with regard to the growing importance of the prime minister in the politics of European democracies (see Poguntke/Webb 2005). The prime minister is the actor who determines, or at least codetermines, the composition of his/her cabinet, sets the agenda for government policies and creates the overall image of the cabinet ${ }^{7}$. It can be argued that if the prime minister is a member of a political party, his cabinet cannot be considered as technocratic, even if all the cabinet members are technocrats (cf. McDonnell/Valbruzzi 20I4, 657 - footnote no. I). In practice, this is probably little more than a theoretical assumption. However, empirical evidence shows the frequent appearance of an opposite case: a cabinet headed by a technocrat whose team is mostly composed of partisans. It is even possible to identify several cabinets in Europe in which the prime minister was the only technocrat: two cabinets led by A. Škele in Latvia (1995-7), Isarescu's cabinet in Romania (1999-2000) and the Cvetković cabinet in Serbia (2008I2) (for details see B 92 2008; Marangos 2004, 263-264; Holmes 2006, 58; Jeffries 2002, 47-48).

On the other hand, there are examples of technocratic cabinets that approach the ideal type of technocratic cabinet (entirely made up of technocrats). Mario Monti's cabinet in Italy (2OII-I3), Jiř́ Rusnok's cabinet in the Czech Republic (2013-I4), and Reino Lehto's cabinet (1963-4) in Finland (Nousiainen 2000) are cases in point.

\section{Remit of technocratic cabinets}

The second important (but not defining) characteristic often associated with the technocratic cabinet is its remit, i.e. the scope of activities the technocratic cabinet is allowed to conduct. As early as 1958, Kuusisto - and again very recently McDonnell and Valbruzzi - pointed out that technocratic cabinets should not be confused with caretaker cabinets (Kuusisto 1958, 342; McDonnell/ Valbruzzi 20I4, 66I-2). However, in a number of texts these two concepts seem to be conflated (e.g. Nousiainen

7 However, in the constitutional practice of a number of parliamentary democracies this may not be the case given the fact that the overall position of prime minister tends to be rather weak. 
2000; Blondel/Müller-Rommel 200I, 64-7I; Amorim Neto/Strøm 2002, 7-8; cf. Hloušek/Kopeček 20I4). To be sure, the notion of a caretaker cabinet is different in principle. Whereas the technocratic cabinet is defined in terms of composition (non-partisan nature), the caretaker cabinet is defined by its limited remit. As Diermeier and Roozendaal put it: "Caretaker cabinets typically only have a limited political agenda, for a relatively small period of time. Often caretaker governments are formed to bridge a certain period of time until new general elections can be held" (Diermeier/Roozendaal I998, 620; cf. Schleiter/Morgan-Jones 2009, 674; Herman/ Pope 1973, 196; Laver/Shepsle 1996, 46-7; Amorim Neto/ Strøm 2002, 9).

Admittedly, there are a number of examples of technocratic cabinets that also served as caretaker cabinets, e.g. the Greek cabinets of Grivas and Zolotas between I989 and 1990. Yet purely partisan caretaker cabinets also emerge (cf. Schleiter/Belu 20I4), i.e. party cabinets that resign, but remain in office (as caretaker cabinets) until a new cabinet is formed. Laver and Budge even assume that caretaker cabinets are partisan cabinets (Laver/Budge 2002, I2).

McDonnell and Valbruzzi created a simple typology of technocratic cabinets based on composition (a majority vs. a minority of technocrats) and remit (cabinets whose task is only administration and "minding the shop" vs. cabinets that are allowed to make major changes) (McDonnell/Valbruzzi 20I4, 664)

I) Full-technocratic governments (with a majority of technocrats and a mandate to change the status quo)

2) Non-partisan caretaker (with a majority of technocrats and no mandate to change the status quo)

3) Technocrat-led partisan governments (with a majority of partisans and a mandate to change the status quo)

4) Partisan caretaker (with a majority of partisans and no mandate to change the status quo).

However, it remains unclear where the dividing line between maintaining and changing the status quo should be drawn. It can be argued that every cabinet changes something, and it therefore becomes a matter of attempting to assess whether the cabinet has undertaken measures that could be considered insignificant (i.e. keeping the status quo) or whether the changes are in fact significant. The lack of clarity in this regard may cast some doubts on McDonnell and Valbruzzi's categorisation of technocratic cabinets. For example, they argue that the cabinet formed by Jan Fischer in the Czech Republic was a "full technocratic cabinet", e.g. with a mandate to change the status quo. However, Fischer,

8 The authors refer to Golder who states that caretaker cabinets "should simply maintain the status quo" (Golder 20IO, 4). addressing MPs shortly before a parliamentary vote of confidence, said that "this government is not a classic cabinet in the political sense. It is not a cabinet of parties or a coalition of parties. It is a team made up of specialists, albeit nominated by the parties, and headed by a completely non-political premier. Therefore the task of the government is not the achievement of a political programme, but quality, non-partisan, and insofar as possible, politically neutral administration of the country... besides the state budget for next year, it will endeavour only to complete the legislative process with those laws which are of fundamentally technical nature, or enjoy support across the political spectrum" (quoted from Hloušek/Kopeček 20I4, I343)9. Fischer's address seems to indicate that his cabinet was not fully technocratic; it promised not to pursue initiatives to change the status quo.

Based on the lack of consensus in regard to this example, it becomes useful to introduce two clear limitations of remit. The first type of constraint is derived from formal constitutional provisions. For example, the Portuguese constitution states that "after its dismissal, the Government has to limit itself to those acts which are strictly necessary to ensure the management of public business" (art. 189/5). Similar provisions can be found in the Danish (art. I5) or Slovak (art. II5 and II9) constitutions. It is interesting to note that the Greek constitution expects a technocratic (and at the same time caretaker) government if the procedure to form a standard political cabinet fails. In this case, the president "shall entrust the President of the Supreme Administrative Court or of the Supreme Civil and Criminal Court or of the Court of Auditors to form a Cabinet as widely accepted as possible to carry out elections and dissolve Parliament" (art. 37). Similarly the Croatian president "shall appoint an interim non-partisan Government and simultaneously call an early election for the Croatian Parliament" (art. II2) if the government formation process does not result in a cabinet that can enjoy the confidence of a parliamentary majority.

The second type of constraint is imposed by the political parties which give rise to the technocratic cabinet; a deal is formed stipulating that the technocratic government will not make changes to the status quo. For example, the cabinet formed by Alexandras Abišala in Lithuania gave up submitting new proposals and undertaking steps geared towards reform. His aim was to defend economic reforms implemented by his predecessor Gediminas Vagnorius (Clark 1995, 7I). Moreover, the cabinets of Indzhova and Raykov in Bulgaria were caretaker cabinets with a limited remit (see Dimitrov et

9 It should be noted, however, that the cabinet remained in power several months longer than was originally expected and that the cabinet was forced to carry out policies which were not originally considered (Hloušek/Kopeček 2OI2, 78-82). 
al. 2006, I62; Jensen 2008, 66; Jalalzai 20I3, 20I; Sofia Globe 20I3). Thus, analyses of the remit in terms of the status quo might be completed by studying the remit in terms of formal (constitutional) and/or political constraints. Still, there remains another question open to further research: there are cases of technocratic cabinets which had limited mandates, e.g. they were restricted to actions designed to deal with an economic crisis. However, a limited mandate does not necessarily mean a weak agenda. As Marangoni and Verzichelli say in relation to the Monti cabinet in Italy: "Given the magnitude of the crisis, the cabinet was able to use all the "preferential procedures' provided for by parliamentary rules on governmental action, and above all it could force legislators to intervene in other policy areas that were not supposed to be directly affected by 'governmental pledges'. Such policy actions included, for instance, the institutional arrangements to reduce the cost of politics, and the reform of local government administration, of public funding of political parties, and of Italy's electoral system" (Marangoni/Verzichelli 20I5, 4I; see also Pasquino/Valbruzzi 2OI2, 62O; Marangoni 2OI2). It is therefore important to examine not only the scope of the agenda, i.e. to what extent the remit of the technocratic cabinet is limited, but also to what extent the technocratic cabinet is able to push through its policy plans. There might be a technocratic cabinet with a limited remit, but at the same time it might be capable of putting all of the priorities on its agenda into practice (as exemplified by the three Italian technocratic cabinets - see Pasquino/Valbruzzi 20I2, 629), and there can be a party political cabinet without a limited remit, but also without the capability to accomplish any of its prioritised policy objectives.

\section{Term of office}

Although it is often assumed that technocratic cabinets are constrained in terms of the time that they may remain in office, in principle there are no automatic reasons to argue that the term of office of a technocratic cabinet is always limited. True, those technocratic cabinets that have been established as caretaker governments have tended to be highly restricted in this regard (cf. Herman/Pope 1973, 205; Schleiter/Morgan-Jones 2009, 672). However, not all technocratic cabinets are constrained by limited terms of office. An example is the Tarlev cabinet that was formed following the parliamentary elections in Moldova (East/Thomas 2003, 356; Tomiuc 200I). Other examples can be found in Macedonia, e.g. the Kljusev cabinet (Bideleux/Jeffries 2007, 4II); or Serbia, e.g. the Cvetković cabinet (B92 2008). Furthermore, the limited term of office may not automatically translate into a limited remit. Some technocratic cabinets are established as "crisis-liquidation cabinets" whose task is not to "mind the shop" but to instead pursue drastic measures and push through important reforms. The Monti cabinets in Italy (Pasquino/Valbruzzi 2OI2; Tebaldi 20I4) and the Bajnai cabinet in Hungary (Sparks 20I0, 409) are cases in point.

\section{Why and when are technocratic cabinets formed?}

One of the crucial questions (which remains largely unexplored) is why technocratic cabinets are formed in the first place. In other words, one should ask under which conditions technocratic cabinets are given priority over standard (partisan) cabinets. An important distinction between the partisan and technocratic government is found in the way the cabinet is legitimised. As for those technocratic governments which cannot always count on the reliable support of a political party's majority in parliament, it is usually assumed that their authority arises from their specialised knowledge, experience and insight into complex issues (cf. Strøm 2003, 57; Dowding/Dumont 2008, 7). In contrast, partisan governments are legitimised by a mandate which emerges from an electoral reflection of the popular will (cf. Cochrane 1967). Thus, in theory, competence, efficiency, expertise and specialisation belong to one group of sources of legitimacy as opposed to electoral legitimacy and political loyalty (Cotta/Verzichelli 2003, I09), although in practice party cabinets tend to pride themselves on having expertise and competence too.

So, why does competence take precedence over the electoral mandate? It appears difficult to construct any general model that would relate the rise of technocratic cabinets to a particular set of conditions. The formation of any cabinet is usually an outcome of a number of factors, some of which are transparent, some of which may relate to motivations that may be obscured or hidden. As a result, the real reasons for the rise of a cabinet may remain unclear or open to dispute. However, the question of "why" can be reformulated to the question of "when" (or under which circumstances) a technocratic cabinet is formed. A good start to providing at least a tentative answer to this question is made by collecting empirical evidence on "critical situations" in which technocratic cabinets have been formed.

To begin with, the most recent examples of technocratic cabinets are related to economic crises as exemplified by the technocratic cabinets that took shape in Italy, Greece and Bulgaria. These technocratic cabinets, which consisted of economic experts and crisis managers, were supposed to avert imminent economic disasters. However, deep economic or financial crises also affected other countries, yet they saw no formation of technocratic cabinets. The converse is also true: in a number of cases technocratic cabinets have come into existence despite 
there being no evident economic crisis, e.g. the Portuguese technocratic cabinets of between 1978 and 1979 (Magone 2003, 552-3).

Hence, it is clear that the answer to the crucial question should go beyond economic crises and that we should broaden the scope of our understanding of critical situations.

Since the concept of technocratic cabinets is based on (non-partisan) composition, the second situation in which a technocratic cabinet may be formed is when parties (partisan cabinets) fail ${ }^{10}$. Empirical evidence shows that the reasons for such a failure may be multi-farious: first and foremost, parties can fail to form a cabinet following parliamentary elections. An example of such a bargaining failure may be the situation that arose following the 1992 parliamentary elections in Romania. At that particular juncture, president Iliescu tried to form a government of national unity. However, the Romanian Democratic Convention refused to join the cabinet and hoped that the government of the Democratic National Salvation Front would not survive the winter at the turn of 1992 and 1993 . However, president Iliescu finally appointed a technocratic cabinet headed by non-partisan Nicolae Vacaroiu (Weiner 1994, I27-8). The second instance in which parties fail to create a cabinet occurs when a previous party (coalition) cabinet has broken up and parliamentary parties are unable to reach a compromise for a new cabinet. Lehto's technocratic cabinet was formed amid such a situation that existed in Finland in 1963 (Jussila 1999, 289). The third instance is when parties face a serious legitimacy crisis. The parties are (at least temporarily) considered corrupt or otherwise disqualified from forming a cabinet. As a result a non-partisan technocratic cabinet is seen as a good and legitimate solution to the crisis. Such critical events are well demonstrated by the Italian Ciampi cabinet of 1993 (cf. Cotta/Verzichelli 2003, I34-I35) or the Czech technocratic cabinet led by Josef Tošovský in 1998 (Hloušek/ Kopeček 2014). The fourth instance sees parties fail to produce their own candidates to fill the posts of prime minister and other ministers, e.g. the Macedonian cabinet of Kljusev in I99I (cf. Bideleux/Jeffries 2007, 4II4I4). This situation may relate to nascent party systems. It is not by chance that many technocratic cabinets were formed in the former post-communist countries in the early I990s when political parties and party systems were only emerging: the cabinets relevant here are $\mathrm{Ah}$ meti (199I) and Bufi (199I-2) in Albania, Berov (1992-4) and Indzhova (1994-5) in Bulgaria, Vähi (1992) in Estonia, Prunskiene (1990-I), Abišala (1992) and Lubys (1992-3) in Lithuania, Škele (1995-7) in Latvia, Kljusev

IO To be clear, „economic crisis“ factor can be also regarded as a type of party failure, because technocratic cabinets are often appointed when (partisan) cabinets failed to deliver expected economic policy outcomes.
(1991-2) in Macedonia and Vacaroiu (1992-6) in Romania. It is appreciable that the rise of these cabinets may be explained by a context of weak political parties (lacking qualified political personnel ${ }^{\mathrm{II}}$ ) and low-level party system institutionalisation characterised (among other things) by greater electoral instability (cf. Mainwaring/ Torcal 2006; Casal Bertóa/Mair 2010). Another type of party failure may arise when a partisan cabinet is defeated by a parliamentary opposition which is, however, not strong enough, to form its own cabinet. Thus, a technocratic cabinet might be an emergency way out of a crisis. The Czech cabinet led by Jan Fischer in 2009 (Hloušek/ Kopeček 2014, 1342) is a good case in point.

The third critical situation that may facilitate the rise of a technocratic cabinet is a powerful president. This situation is typical in East-Central Europe (especially in Russia and Ukraine), and the Caucasus states, where a number of technocratic "presidential" cabinets have been formed. In Ukraine, for instance, powerful presidents were key players in the appointment and dismissal of entirely nonpartisan governments in the I990s (cf. Protsyk 2003). Moreover, the Portuguese president Eanes appointed three technocratic cabinets in a row between 1978 and 1979 (the cabinets Nobre da Costa, Mota Pinto and Pintassilgo). Even formally (constitutionally) less powerful but politically strong presidents who are able to use the legitimacy advantage (Protsyk 2005) occasionally appoint a technocratic presidential cabinet. For example, Bulgarian president Z. Zhelev appointed Berov's technocratic cabinet in 1992. Similarly, Czech president Zeman appointed the Rusnok technocratic cabinet in 2013. In sum, a powerful (in formal or informal terms) president may be tempted to recall a partisan cabinet and appoint a technocratic cabinet over which he/she can have full control, as the cabinet ministers are cut off from parties to which they are not accountable (for details on this point see Shugart 1998; Schleiter/ Morgan-Jones 2009; Herzig 1999; Amorim Neto/Strøm 2006; Schleiter 2013).

Finally, there are technocratic cabinets that have been established in critical situations which cannot be easily classified by the above outlined categories. These cases fall into a residual category. For example, the Romanian technocratic premier Mugur Isarescu was appointed in order to unblock a constitutional stalemate. The previous prime minister, Radu Vasile, was recalled by president Emil Constantinescu. Opposition parties and constitutional experts nevertheless asserted that this presidential move was unconstitutional. Vasile

II The lack of personnel was often made up for by prime ministers chosen from a large pool of former members of communist parties (e.g. Tošovský in the Czech Republic, Prunskiene in Lithuania, Vacaroiu in Lithuania, and Fokin, Masol, Kuchma and Marchuk in Ukraine). In contrast to new politicians who lacked political experience, these people had worked in various state institutions during the period of communist rule. 
eventually resigned and Isarescu was appointed as a compromise candidate to solve the constitutional conflict (Jeffries 2002, 47-8). All the various types of critical situation are summarised in the table below.

Table 1: Critical situations in which technocratic cabinets are formed

1. Economic crisis

2. Party failure

a. Inability to form a cabinet following parliamentary elections

b. Break-up of a previous cabinet

c. Political party's crisis of legitimacy

d. Weakness of parties in terms of personnel

e. Defeat of a cabinet by opposition parties

3. Presidential factor

4. Other

In political practice the above critical situations may manifest themselves simultaneously. For example, the confluence of several critical situations has been documented in the rise of the Ciampi (1993) and Monti (20II) cabinets in Italy (cf. Grimaldi 20II, IO9-III; Pastorella 20I3; Marangoni/Verzichelli 20I5).

The above overview of critical situations shows that technocratic cabinets are formed not only when parties fail, i.e. the parties are unable to form partisan cabinets (typically in the second group of critical situations, examples of which are documented above), but also when they are unwilling (most likely in situation no. I), or are not allowed (most likely in situation no. 3) to form a partisan cabinet. On the face of it, a situation in which parties would not be willing to form a cabinet and would voluntarily withdraw from bargaining over the new government may seem unlikely. However, an almost textbook case of such a situation occurred in Italy in $201 \mathrm{I}$ when the Monti technocratic cabinet was established. At that time Italy was plagued by a deep financial crisis. Simultaneously, parliamentary political parties were refusing to accept the responsibility of government because it was clear that the administration would have to push through very unpopular and painful measures to stabilise the Italian economy and public budgets. Thus the parties conceded the reins of government to Monti's technocratic government mainly formed by the president. The parties remained rather passive in the government formation process (Zulianello 2OI3; cf. Marangoni 20I2; Pasquino, Valbruzzi 20I2). Finally, as has been indicated above, a situation in which parties are prevented from forming a new cabinet can be likely in a regime with a powerful president. Instead of appointing partisan cabinets reflecting the will of parliamentary parties, the president can opt to impose a technocratic cabinet. This approach has been exemplified by a number of presidential, and at the same time technocratic, cabinets in Russia (cf. Morgan-Jones, Schleiter 2004; Sedelius 2006; Schleiter 20I3) and Ukraine (Protsyk 2003). A presidential technocratic cabinet was also established in the Czech Republic in 2013 when the first popularly elected president, Miloš Zeman, took advantage of his legitimacy advantage and appointed Rusnok's technocratic cabinet. His move ran contrary to the will of parliamentary parties which had intended to form a new partisan cabinet (immediately or after early elections).

\section{Parties and technocratic cabinets}

Another factor which remains unaddressed in comparative research is the degree of influence exerted by political parties on the composition and policies of technocratic cabinets. This question results from the above-mentioned concept of the ideal typical technocratic cabinet, but no author has addressed this issue in detail. This problem of influence is complicated by the fact that the share of partisans in a technocratic cabinet may not correlate with the level of partisan influence on the technocratic cabinet. For example, the Fischer cabinet (2009-IO) in the Czech Republic was completely composed of technocrats (i.e. non-partisans). However, all of these technocrats had close ties to political parties which kept an eye on the cabinet and its policies. Paradoxically enough, another Czech technocratic cabinet - that of Tošovský (1998) - was much less constrained by party influence as Tošovský was to a large extent autonomous and the parties did not have much say in the overall cabinet performance and in policy, even though the non-partisan side of the cabinet amounted to only 38 percent! (For details see Hloušek/Kopeček 20I2; Hloušek/Kopeček 20I4). It should be borne in mind that in most cases technocratic cabinets do not completely lack a political background. They need active support (or at least tolerance) from the political parties, both when asking for a show of confidence that enables them to take office and when pursuing their policies. Although assessing the level of influence parties have over cabinet composition and policy formation is extremely difficult, it is worth exploring the extent to which parties maintain this control. Finally, there is the problem of parliamentary support for technocratic cabinets. As political parties are usually not significantly represented in technocratic cabinets, they might feel less obliged to support these cabinets perpetually and unconditionally. In other words, there is a difference between a political party's support for a technocratic cabinet during 
the cabinet formation process (and/or at a crucial vote of confidence) on the one hand, and that political party's support for the technocratic cabinet and its policies on the other hand. For example, the newly appointed cabinet of Monti gained by far the largest support seen in decades at a vote of confidence in both of Italy's parliamentary chambers (Marangoni 20I2, I38). However, once it became clear that the potential costs of supporting the Monti cabinet were outweighing the benefits, some parties (especially the People of Freedom) withdrew their support and Monti was eventually forced to resign (Zulianello 20I3; Tebaldi 20I4: 57I-2). Hence, we need to know more about the trajectories of parliamentary support for technocratic cabinets in comparison to partisan cabinets.

\section{Conclusion}

Despite the fact that the political practices of European countries exhibit various patterns when it comes to technocratic cabinets, this topic has remained a largely unexplored field within comparative politics. This article has reviewed the research conducted to date on technocratic cabinets and has addressed major variables (composition, remit and term of office) connected with such cabinets. However, only the composition variable is a defining characteristic of technocratic cabinets that are delineated as cabinets headed by a non-partisan (i.e. technocratic) prime minister, even where partisans may outnumber non-partisans in a technocratic cabinet. Even though the remit and the term of office are important variables of a technocratic cabinet, they can hardly become its defining features, because, as our preliminary empirical analysis has shown, technocratic cabinets may not always be limited in terms of a) their policy agenda and $b$ ) the time they remain in office. The article has also discussed the crucial question of under which circumstances technocratic cabinets are formed. Conventional wisdom tends to attribute the rise of technocratic cabinets to economic crises, but this article has shown that these cabinets are also formed under other various circumstances related, for example, to a party's failure (and the different forms of that), or powerful presidents.

Although the above-mentioned themes are highly relevant and important, they are a long way from exhausting the full research potential in regard to technocratic cabinets. There remain several further important questions that need to be addressed in future research:

- Why are technocratic cabinets quite often formed in some countries, whereas other states have never seen the formation of a technocratic cabinet?

- What role do political parties play in the technocratic cabinet formation process?
- To what extent do parties control the composition and agendas of technocratic cabinets?

- To what extent are the technocratic cabinets capable of putting their policy agenda into practice compared to political party cabinets?

- Is governing through a technocratic cabinet different from governing through a partisan cabinet? Do technocratic cabinets outperform partisan cabinets in the quality of their policies and outcomes?

- Given the low levels of legitimacy of the political parties evident in a number of democracies, to what extent can technocratic cabinets (and the legitimacy held by experts) be perceived as alternatives to standard political party cabinets (and their electoral legitimacy)?

\section{Literature}

Amorim Neto, Octavio/Kaare Strøm (2002). Presidents, Voters, and Non-Partisan Cabinet Members in European Parliamentary Democracies, Joint Sessions of the Nordic Political Science Association, Aalborg.

Amorim Neto, Octavio/Kaare Strøm (2006). Breaking the Parliamentary Chain of Delegation: Presidents and Non-partisan Cabinet Members in European Democracies, in: British Journal of Political Science, Vol. 36(4), 619-43.

B 92 (2008). Parliament meets for cabinet vote. Internet: http://www.b92.net/eng/news/politics.php? yyyy= $2008 \& \mathrm{~mm}=07 \& \mathrm{dd}=06 \&$ nav_id $=51669$ [Accessed 22. 3. 2014].

Baramova, Spasena (2008). New Serbian prime minister named, The Sofia Echo, 28. 6. 2008. Internet: http:// sofiaecho.com/2008/06/28/661790_new-serbianprime-minister-named [Accessed 20. 8. 2014].

Bideleux, Robert/Ian Jeffries (2007). The Balkans: A postcommunist history, London, New York.

Blondel, Jean/Ferdinand Müller-Rommel (1988). Cabinets in Western Europe, Houndmills, Basingstoke, Hampshire.

Blondel, Jean/Ferdinand Müller-Rommel (200I). Cabinets in Eastern Europe, Gordonsville.

Bryld, Erik (2000). The technocratic discourse: technical means to political problems, in: Development in Practice, Vol. IO(5), 700-705.

Casal Bértoa, Fernando/Peter Mair (2010). Two Decades On: How Institutionalized are the Post-Communist Party Systems? European University Institute. Internet: http://cadmus.eui.eu/handle/I8I4/I4594 [Accessed 20. 8. 20I4].

Collier, David (ed.). (1979). The New Authoritarianism in Latin America, Princeton. 
Cotta, Maurizio/ Luca Verzichelli (2003). Ministers in Italy: Notables, Party Men, Technocrats and Media Men, in Pedro De Almeida/Antonio Costa Pinto/Nancy Bermeo (eds.): Who Governs Southern Europe? Regime change and ministerial recruitment, I8502000, London, IO9-I42.

Cochrane, James (1967). Mexico's New Científicos: The Díaz Ordaz Cabinet, in: Inter-American Economic Affairs, Vol. 2I(I), 6I-72.

Diermeier, Daniel/Peter Van Roozendaal (1998). The duration of cabinet formation processes in western multi-party democracies, in: British Journal of Political Science, Vol. 28 (4), 609-626.

Dimitrov, Veselin/ Klaus Goetz/Hellmut Wollmann (2006). Governing after communism: institutions and policymaking, Lanham.

Dowding, Keith/Patrick Dumont (2008). Structural and strategic factors affecting the hiring and firing of ministers, in: Keith Dowding/Patrick Dumont (eds.): The selection of ministers in Europe: hiring and firing, New York.

East, Roger/Richard Thomas (2003). Profiles of people in power: the world's government leaders, London.

Golder, Sona N. (20IO). Bargaining Delays in the Government Formation Process, in: Comparative Political Studies, Vol. 43(I), 3-32.

Grimaldi, Selena (20II). The Role of Italian Presidents: The Subtle Boundary between Accountability and Political Action, in: Bulleting of Italian Politics, Vol. 3(I), IO3-I25.

Herman, Valentin/John Pope (1973). Minority governments in western democracies, in: British Journal of Political Science, Vol. 3(2), I9I-2I2.

Herzig, Edmund (1999). The New Caucasus: Armenia, Azerbaijan and Georgia, London.

Hloušek, Vít/Lubomír Kopeček (2012). Záchrana státu? Úřednické a polopolitické vlády v České republice a Československu, Brno.

Hloušek, Vít/Lubomír Kopeček (20I4). Caretaker Governments in Czech Politics: What to Do about a Government Crisis, in: Europe-Asia Studies, Vol. 66(8), I323I349.

Holmes, Leslie (2006). Rotten states? Corruption, postcommunism, and neoliberalism, Durham.

Hopkin, Jonathan (2012). Technocrats have taken over governments in Southern Europe. This is a challenge to democracy. Internet: http://blogs.lse.ac.uk/europpblog/2OI2/O4/24/technocrats-democracy-southern-europe [Accessed 6. 2. 20I3].

Huskey, Eugene (20IO). Elite recruitment and state-society relations in technocratic authoritarian regimes: The Russian case, in: Communist and post-communist studies, Vol. 43(4), 363-372.
Jalalzai, Farida (20I3). Shattered, Cracked, Or Firmly Intact?: Women and the Executive Glass Ceiling Worldwide, Oxford.

Jeffries, Ian (2002). Eastern Europe at the Turn of the Twenty-first Century: A Guide to the Economies in Transition, London.

Jensen, Jane S. (2008). Women Political Leaders, Houndmills, Basingstoke.

Jussila, Osmo (1999). From grand duchy to modern state: a political history of Finland since I809, London.

Katz, Richard S. (1986). Party government: A rationalistic conception, in Francis. G. Castles/Rudolf Wildenmann (eds.): Visions and realities of party government, Florence/Berlin.

Katz, Richard S. (1987). Party government and its alternatives' in Richard S. Katz (ed.): Party governments: European and American experiences. Florence/Berlin.

Kuusisto, Alan (1958). Parliamentary crises and presidial governments in Finland, in: Parliamentary Affairs, Vol. II(3), 34I-349.

Laver, Michael/Kenneth Shepsle (eds.) (1996). Making and breaking governments: Cabinets and legislatures in parliamentary democracies, Cambridge.

Laver, Michael/Norman Schofield (1998). Multiparty government: The politics of coalition in Europe, Ann Arbor.

Laver, Michael/Ian Budge (eds.) (2002). Party policy and government coalitions, Houndsmills.

MacDougall, John J. (1976). The Technocratic Model of Modernization: The Case of Indonesia's New Order, in: Asian Survey , Vol. I6(I2), II66-83.

Mainwaring, Scott/Mariano Torcal (2006). Party system institutionalization and party system theory after the third wave of democratization, in William Crotty/ Richard Katz (ed.): Handbook of party politics, London.

Marangoni, Francesco (2012). Technocrats in Government: The Composition and Legislative Initiatives of the Monti Government Eight Months into its Term of Office, in: Bulletin of Italian Politics, Vol. 4 (I), I35I49.

Marangoni Francesco/Luca Verzichelli (2015). From a Technocratic Solution to a Fragile Grand Coalition: The Impact of the Economic Crisis on Parliamentary Government in Italy, in: The Journal of Legislative Studies, Vol. $2 \mathrm{I}(\mathrm{I}), 35-53$.

Marangos, John (2004). Alternative economic models of transition, New Jersey.

McDonnell, Duncan/Marcod Valbruzzi (2014). Defining and classifying technocrat-led and technocratic governments, in: European Journal of Political Research, Vol. 53(4), 654-67I.

Meynaud, Jean (1969). Technocracy, New York. 
Milne, R. Stephen (1982). Technocrats and Politics in the ASEAN Countries, Pacific Affairs, Vol. 55(3), 403-429.

Müller, Wolfgang/Kaare Strøm (eds.) (2000). Coalition Governments in Western Europe, Oxford.

Nousiainen, Jaakko (2000). Finland. The Consolidation of Parliamentary Governance, in Wolfgang C. Müller/ Kaare Strøm (eds.): Coalition Governments in Western Europe, Oxford, 264-299.

Pastorella, Gulia (2013). Technocratic governments during the Eurocrisis: nothing new under the sun?, Thesesus PhD Workshop, Paris, 2I-22 May 2013.

Pastorella, Gulia (20I4). Why have technocrats been appointed to govern European democracies? UACES General Conference Panel: Public opinion, representation and citizenship: political parties, distrust, and compliance Cork, September 2014.

Pastorella, Gulia (2015). Technocratic Governments in Europe: Getting the Critique Right. Political Studies I-I7.

Pasquino, Gianfranco/Marco Valbruzzi (2012). Non-partisan governments Italian-style: decision-making and accountability, Journal of Modern Italian Studies, Vol. I7 (5), 6I2-629.

Poguntke, Thomas/Paul Webb (eds.) (2005). The presidentialization of politics: A comparative study of modern democracies, Oxford.

Protsyk, Oleh (2003). Troubled Semi-Presidentialism: Stability of the Constitutional System and Cabinet in Ukraine, in: Europe-Asia Studies, Vol. 55 (7), IO77I095.

Protsyk, Oleh (2005). Prime Ministers' Identity in SemiPresidential Regimes: Constitutional Norms and Cabinet Formation Outcomes, in: European Journal of Political Research, Vol. 44(5), 72 I-748.

Putnam, Robert D. (1977). Elite Transformation in Advanced Industrial Societies. An Empirical Assessment of the Theory of Technocracy, in: Comparative Political Studies, Vol. IO(3), 383-4I2.

Schleiter, Petra/Edward Morgan-Jones (2005). Semi-Presidential Regimes: Providing Flexibility or Generating Representation and Governance Problems?, Presented at the Annual Meeting of the American Political Science Association, Washington DC, September I-4, 2005 .

Schleiter, Petra/Edward Morgan-Jones (2009). Party Government in Europe? Parliamentary and semipresidential democracies compared, in: European Journal of Political Research, Vol. 48(5), 665-693.

Schleiter, Petra (2013). Democracy, Authoritarianism, and Ministerial Selection in Russia: How Presidential Preferences Shape Technocratic Cabinets, in: PostSoviet Affairs, Vol. 29(I), 3I-55.

Schleiter, Petra/Valerie Belu (2014). The Challenge of Periods of Caretaker Government in the UK, in: Parliamentary Affairs, Vol. 68(I), I-I9.
Sedelius, Thomas (2006). The Tug-of-War between Presidents and Prime Ministers. Semi-Presidentialism in Central and Eastern Europe, Örebro.

Schudson, Michael (2006). The Trouble with Experts - and Why Democracies Need Them, in: Theory and Society, Vol. 35 (5/6), 49I-506.

Shugart, Matthew S. (1998). The Inverse Relationship between Party Strength and Executive Strength: A Theory of Politicians' Constitutional Choices, in: British Journal of Political Science, Vol. 28(I), I-29.

Silva, Patricio (2010). In the name of reason: Technocrats and politics in Chile.

Sofia Globe (2013). Bulgarian President Plevneliev names ambassador Marin Raykov as caretaker prime minister. Internet: http://sofiaglobe.com/2OI3/o3/I2/ bulgarianpresident-plevneliev-names-ambassadormarin-raikov-as-caretaker-prime-minister/ [Accessed I2. 3. 2OI3].

Sparks, Karen J. (ed.). (20I0). Britannica Book of the Year 20Io, London.

Strøm, Kaare (2003). Parliamentary Democracy and Delegation, in Kaare Strøm/Wolfgang C. Müller/Torbjörn Bergman (eds.): Delegation and accountability in parliamentary democracies, Oxford, 55-IO8.

Strøm, Kaare/Wolfgang Müller/Torbjörn Bergman (2008). Cabinets and coalition bargaining: the democratic life cycle in Western Europe, Oxford.

Suleiman, Ezra N. (1977). The Myth of Technical Expertise: Selection, Organization, and Leadership, in: Comparative Politics, Vol. IO (I), I37-I58.

Tebaldi, Mauro (2014). From Notary to Ruler: The Role of the President of the Republic during the Italian Crisis (2OIO-I4), in: South European Society and Politics, Vol. I9(4), I-2I.

Tomiuc, Eugen (200I). Moldova: New Government Gives Mixed Signals, Internet: http://www.rferl.org/content/article/IO96265.html [Accessed I2. 3. 20I3].

Tucker, Aviezer et al. (2000). From Republican Virtue to Technology of Political Power: Three Episodes of Czech Nonpolitical Politics, in: Political Science Quarterly, Vol. II5(3), 42I-445.

Verzichelli, Luca/Maurizio Cotta (20I2). Technicians, technical government and non-partisan ministers. The Italian experience, CIRCaP - University of Siena, IPSA XXII Congress, Madrid, July 20I2 Panel: Experts and Non-partisan Ministers in European Democracies.

Zulianello, Mattia (20I3). When Political Parties Decided Not to Govern. Party Strategies and the Winners and Losers of the Monti Technocratic Government, in: Contemporary Italian Politics, Vol. 5(3), 244-26I. 


\section{Autor}

Dr. Milos Brunclík , Ph.D. ( ${ }^{*}$ I98I) specializes in constitutional and party systems. His research focuses on the theory and practice of parliamentary and semi-presidential systems. He is the author of numerous articles in peer-reviewed journals. 